\title{
СТРАТЕГИЧЕСКИЕ ОРИЕНТИРЫ ЛОКАЛИЗАЦИИ СОВМЕСТНОГО ПРОИЗВОДСТВА В РОССИЙСКОЙ ПРОМЫШЛЕННОСТИ
}

\author{
(C) 2020 Волкодавова Елена Викторовна \\ доктор экономических наук, профессор \\ Самарский государственный экономический университет, Россия, Самара \\ E-mail:vev.sseu@gmail.com \\ (c) 2020 Жабин Александр Петрович \\ доктор экономических наук, профессор \\ Самарский государственный экономический университет, Россия, Самара \\ E-mail: apzhabin@yandex.ru
}

В статье исследуются вопросы импортозамещения в российский промышленности на основе одного из самых эффективных его инструментов - локализации. Сформулированы стратегические ориентиры, преимущества, недостатки и проблемы, связанные с реализацией процесса локализации в российской промышленности в условиях намечающегося мирового экономического кризиса и метод ее решения, основанный на применении специального инвестиционного контракта.

Ключевые слова: локализация, преимущества, проблемы, мировой кризис, импорт, экспорт, промышленное производство, импортозамещение, специальный инвестиционный контракт.

В соответствии с Указом Президента России «О национальных целях и стратегических задачах развития Российской Федерации на период до 2024 года» от 7 мая 2018 г. № 204 [1], Правительством России сформированы новые национальные проекты и определены цели и задачи на период до 2024года.

Одной из ключевых задач обозначен экономический рост, который должен произойти за счет дальнейшего развития в стране науки; малого и среднего предпринимательства и поддержки индивидуальной предпринимательской инициативы; цифровой экономики; производительности труда и поддержки занятости; международной кооперации и экспорта.

Среди этих стратегических направлений намечены такие ориентиры экономического роста страны, как международная кооперация и экспорт, которые смело можно назвать локомотивом развития национальной экономики. Действительно, если экономика страны успешно интегрирована в глобальное экономическое пространство, происходит стабильный экономический рост всех ее отраслей по всем направлениям: экономическому, социальному, технологическому, инновационному и т.д.

Экспорт российских товаров неуклонно растет, сальдо внешнеторгового оборота России по абсолютной величине положительное, т.е. объемы экспорта доминируют над объемами импорта. Тем не менее, многолетние исследования авторов на российских промышленных предприятиях, например [2,3], позволяют утверждать, что многие конкурентоспособные товарные позиции, как экспорта, так и продукции для внутреннего потребления, производятся с применением импортных сырья, материалов, комплектующих, оборудования, технологий. Если анализировать динамику импорта товаров, то можно увидеть, что по одним позициям за последние три года импорт растет, а по другим снижается, но не существенно (см. табл 1).

Исследования отечественных авторов, например, Симачева Ю., Кузыка М., Зудина Н. [4] (см. рис.1) также указывают на то, что, многие изделия отечественной промышленности производятся с применением импортных материалов и комплектующих.

Как следует из данных, представленных на рис. 1 , в себестоимости продукции каждого из 14 видов деятельности, присутствуют импортные компоненты. Причем в таких высокотехнологичных видах деятельности, как производство фармацевтической промышленности и автомобилестроение, доля импорта наиболее высока и составляет $50 \%$ и выше, а при производстве станков, медицинской техники и контрольноизмерительных приборов доля импорта выше $40 \%$.

Учитывая вышеизложенное, можно сделать 
Таблица1. Импорт России отдельных важнейших товаров за 2017-2019 г.г.*

\begin{tabular}{|c|c|c|c|c|c|}
\hline \multirow{2}{*}{$\begin{array}{c}\text { Наименование } \\
\text { товара }\end{array}$} & $\begin{array}{c}\text { январь - } \\
\text { декабрь } 2019\end{array}$ & $\begin{array}{c}\text { январь - } \\
\text { декабрь } 2018\end{array}$ & $\begin{array}{c}\text { январь - } \\
\text { декабрь } 2017\end{array}$ & \multirow{2}{*}{$\begin{array}{c}\text { Темп роста } \\
\text { январь - } \\
\text { декабрь } 2019 \\
\text { к январю - } \\
\text { декабрю } 2018 \\
\text { в\% }\end{array}$} & \multirow{2}{*}{$\begin{array}{c}\text { Темп роста } \\
\text { январь - } \\
\text { декабрь } 2018 \\
\text { к январю - } \\
\text { декабрю } 2017 \\
\text { в\% }\end{array}$} \\
\hline & $\begin{array}{l}\text { Млн.долл } \\
\text { США }\end{array}$ & $\begin{array}{l}\text { Млн.долл } \\
\text { США }\end{array}$ & $\begin{array}{l}\text { Млн.долл } \\
\text { США }\end{array}$ & & \\
\hline 1 & 2 & 3 & 4 & 5 & 6 \\
\hline Черные металлы & 5028,0 & 5286,7 & 4825,7 & 95,0 & 108,7 \\
\hline $\begin{array}{l}\text { Черные металлы (кроме чу- } \\
\text { гуна, ферросплавов, отходов } \\
\text { и лома) }\end{array}$ & 4333,9 & 4497,5 & 4190,6 & 96,2 & 106,6 \\
\hline трубы стальные & 1373,1 & 1048,7 & 1044,7 & 130,7 & 100,0 \\
\hline $\begin{array}{l}\text { Металлоконструкции из чер- } \\
\text { ных металлов }\end{array}$ & 814,9 & 659,1 & 662,4 & 123,1 & 99,5 \\
\hline $\begin{array}{l}\text { Сменные рабочие инструмен- } \\
\text { ты для ручных инструментов } \\
\text { и станков }\end{array}$ & 607,2 & 600,1 & 508,6 & 101,1 & 118,0 \\
\hline $\begin{array}{l}\text { Крепежная арматура и фур- } \\
\text { нитура }\end{array}$ & 1039,5 & 1000,1 & 841,8 & 103,9 & 118,8 \\
\hline Механическое оборудование & 43234,9 & 43601,1 & 45300,1 & 99,1 & 96,2 \\
\hline Машины и оборудование & 112544,7 & 112641,9 & 110280,8 & 99,8 & 102,0 \\
\hline Электрическое оборудование & 29770,4 & 29916,2 & 26758,6 & 99,5 & 111,8 \\
\hline Автомобили легковые, 1000 & 7906,1 & 7261,0 & 6697,5 & 108,9 & 108,4 \\
\hline Автомобили грузовые, 1000 & 1936,3 & 1999,0 & 1998,8 & 96,5 & 99,9 \\
\hline $\begin{array}{l}\text { Части и принадлежности мо- } \\
\text { торных транспортных средств }\end{array}$ & 8756,2 & 8978,4 & 8067,5 & 97,4 & 112,9 \\
\hline
\end{tabular}

* Составлено по данным Федеральной таможенной службы РФ, http://customs.ru/folder/515

Вся выборка

Текстильное производство, производство одежды и обуви Обработка древесины, производство изделий из дерева, целлюлозы, бумаги и картона

Химическое производство (кроме фармацевтического) Производство фармацевтической продукции Металлургия, производство готовых металлических изделий

Производство машин и оборудования (кроме станков)

Производство станков

Производство электрических машин и электрооборудования

Производство медицинской техники и контрольно-измерительных приборов Производство вычислительной техники, оборудования для обработки информации, радио, телевидения и связи Автомобилестроение

Судостроение

Производство железнодорожного подвижного состава Производство летательных аппаратов

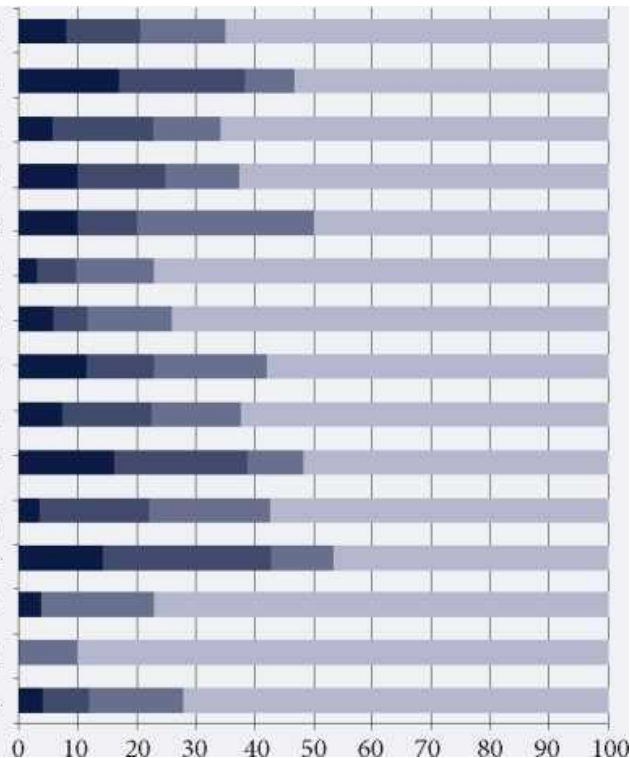

Рис. 1. Доля импорта в себестоимости по отраслям [4]. 
вывод, что импортозамещение остается одной из актуальных задач развития российской экономики. Решением проблемы импортозамещения в российский промышленности Правительство РФ, ученые, практики, занимаются многие годы. Так в статье ВолкодавовойЕ.В., Жабина А.П. [3] проанализирован арсенал инструментов импортозамещения, применявшихся Правительством РФ до 2014 г. В апреле 2014 года Правительством РФ была утверждена новая редакция государственной программы Российской Федерации «Развитие промышленности и повышение ее конкурентоспособности» [5], рассчитанной до 2020 года., и вступил в силу ФЗ N 488-Ф3 «О промышленной политике в Российской Федерации» от 31 декабря 2014 г. [6], где в качестве одного из эффективных инструментов импортозамещения был утвержден специальный инвестиционный контракт (СПИК). Тем не менее доля импортозависимости российской продукции до сих пор велика и импортозамещение остается одной из актуальных задач развития российской экономики.

В данное время, наиболее существенное влияние на мировую, в т.ч. и российскую экономику, оказывают два взаимосвязанных фактора - пандемия короновируса COVID-19 и ее закономерное следствие - сокращение либо прекращение многих экономических мирохозяйственных связей, в виде разрыва долгосрочных торговых отношений и изменения тактики торговых войн между странами, например, между США и Китаем [7].

Все эти события мирового значения закономерно приведут к тому, что для большинства стран, в т.ч. и России, проблема импортозамещения обострится, поэтому вопрос локализации производства на технологической площадке РФ, становится особенно актуальным. С помощью локализации - одного из самых эффективных с позиции сегодняшнего дня инструментов импортозамещения, существует реальная возможность результативно совершенствовать качественную характеристику структуры отечественной экономики, в сторону развития высокотехнологичных производств.

Проблемы и аспекты создания высокопроизводительных локальных производств исследуются в трудах российских ученых, например, $[8,9,10,11,12]$.

С позиции нынешних реалий, стратегию локализации авторы данной статьи формулируют как систему эффективных мер, обеспечивающих снижение импортозависимости, прежде всего в высокотехнологичных наукоемких отраслях, повышающую уровень экономической безопасности страны в долгосрочной перспективе и обеспечивающую последовательную интеграцию российской экономики в глобальные сегменты рынка. Эта рассчитанная на перспективу система мер позволит:

- на микроуровне, обеспечить предприятиюпроизводителю конкурентоустойчивое положение на рынке, увеличить его долю в стоимости производимого изделия;

- на мезоуровне, в регионе локализации производства обеспечить развитие промышленного кластера, что повысит вес участия региона в экономическом развитии страны;

- на макроуровне, локализация производства повысит технологическую и экономическую независимость производства в стране необходимого продукта, снижает импортозависимость экономики.

К основным эффектам локализации промышленного производства, которые могут обеспечить экономический рост российской экономики на микро и мезоуровнях, авторы относят:

- получение новых инновационных технологий, позволяющих интегрировать субъекты российского бизнеса в глобальные цепочки создания стоимости;

- приращение доли добавленной стоимости российского производителя, при производстве готовой продукции;

- новые компетенции предприятия и персонала, которые осваивают новые технологии;

- повышение рыночной стоимости предприятий, осуществляющих успешное импортозамещение;

- создание новых рабочих мест;

- прирост эффективных мощностей в промышленности;

- оптимизацию ценообразования на продукцию, снижение ее цены относительно зарубежного аналога;

- снижение риска изменения валютного курса рубля.

К основным эффектам локализации промышленного производства, которые могут обеспечить экономический рост российской экономики на микро и мезоуровнях, авторы относят:

- формирование высокотехнологичных производств в стране; 
- обеспечение долгосрочного экономического роста;

- формирование и развитие кластерной экономики;

- развитие протекционистской торговой политики на национальном и региональном уровнях;

- модернизацию экономики страны и отрасли;

- качественное осуществление процессов импортозамещения.

Среди основных проблем, сдерживающих развитие локализации в российской промышленности можно отметить:

- технико-технологическую

отсталость многих российских производств;

- кредитную политику российских банков, предоставляющих достаточно «дорогие» кредитные линии.

Для обеспечения успешной реализации стратегии локализации производства в экономике РФ требуются адекватные времени инструменты. К эффективным инструментам развития локализации в России прежде всего следует отнести специальный инвестиционный контракт, внедренный в практику импортозамещения в 2014 г., с помощью которого возможна организация высокотехнологичного производства, повышающего роль страны на мировой экономической платформе. Успешное заключение СПИК можно проследить на примере компании «Фольксваген Груп Рус», которая, в рамках СПИКа, планирует реализовать проект по углублению локализации уже обкатанных на российском рынке моделей автомобилей: VW Polo, Skoda Rapid, Skoda Octavia, Kodiak, Volkswagen Tiguan, Tarek. В частности, предполагается локализация коробки передач и электронных систем управления автомобилем. «Условия специального инвестиционного контракта будут действительны до 2028 года»,- отметил Маркус Озегович, генеральный директор «Фольксваген Груп Рус» [13].

Но до 2020 года специальные инвестиционные контракты могли быть заключены на любые проекты импртозамещения, в т.ч. и «отверточ- ные», что оставляло за отечественным производителем право на вхождение в глобальную цепочку создания стоимости, но на правах пассивного воспроизводства чужой технологии.

Это противоречит современным стратегическим инициативам эффективного развития российской промышленности на основе локализации. В настоящее время в целях привлечения инвестиций в экономику Российской Федерации федеральными органами исполнительной власти разрабатывается усовершенствованный механизм специального инвестиционного контракта (СПИК 2.0) [14].

Согласно комментариям специалистов [15], .. «СПИК 2.0 предусматривает, что инвестор должен создать серийное производство промышленной продукции в России на основе современных технологий, перечень которых утвердит Правительство РФ. Как показывает практика заключения прежних СПИК, уровень экспорта локализованной в России продукции также будет ключевым обязательством инвестора, а от суммы инвестиций будет зависеть срок контракта. В тендере победит тот участник, заявку которого специально созданная комиссия признает лучшей. Оценка комиссии зависит от следующих критериев:

- срок внедрения современной технологии;

- объем производства промышленной продукции;

- технологический уровень локализации производства».

Окончание работы над СПИК 2.0 планировалось в конце марта 2020 г. По известным причинам, пока этого не произошло. Но уже сейчас у Правительства РФ есть эффективный инструмент развития стратегии локализации, основанный на выработке у конкурсантов новых технологических компетенций, а у промышленников, ориентированных на создание высокотехнологичных производств есть возможность увеличить долю добавленной стоимости в произведенной продукции за счет создания предприятий, интегрированных в глобальные цепочки создания стоимости.

\section{Библиографический список}

1 Указ Президента РФ от 7 мая 2018 г. № 204 «О национальных целях и стратегических задачах развития Российской Федерации на период до 2024 года».

2 Жабин А.П., Волкодавова Е.В. Стратегические ориентиры импортозамещения на российских промышленных предприятиях. Вестник Самарского государственного экономического университета. 2016. № 6 (140). С. $82-88$. 
3 Волкодавова Е.В., Жабин А. П., Негонова Н. А. Развитие инструментов импортозамещения в современных условиях ведения бизнеса в промышленности Российской Федерации Интернет-журнал Науковедение. 2016. Т. 8. № 2 (33). С. 27.

4 Симачев Юрий, Кузык Михаил, Зудин Николай Импортозависимость и импортозамещение в российской обрабатывающей промышленности: взгляд бизнеса // Форсайт. 2016. № 4. URL: https://cyberleninka.ru/ article/n/importozavisimost-i-importozameschenie-v-rossiyskoy-obrabatyvayuschey-promyshlennosti-vzglyadbiznesa (дата обращения: 06.04.2020).

5 Правительство Российской Федерации, постановление от 15 апреля 2014 года N 328 «Об утверждении государственной программы Российской Федерации «Развитие промышленности и повышение ее конкурентоспособности»».

6 Российская Федерация, федеральный закон N 488-Ф3 «О промышленной политике в Российской Федерации» от 31 декабря 2014 г. ст. 10-12, 16

7 Тодд Бухгольц. Коронавирус изменил расклады в торговой войне США и Китая - американский эксперт. ЕВРАЗИЯ ЭКСПЕРТ, 25 февраля 2020 г. URL: https://eurasia.expert/koronavirus-izmenil-rasklady-v-torgovoyvoyne-ssha-i-kitaya/ (дата обращения 08.04.2020).

8 Арисова М.Б. Импортозамещение, локализация производств и развитие рынка автокомпонентов в России. Вестник современных исследований. 2018. № 11.8 (26). С. 174-179.

9 Вазьянский А.М., Обыденнова С. Ю. Локализация производства как способ инновационного развития предприятия. Иннов: электронный научный журнал. 2014. № 4 (21). С. 2.

10 Кондратьев В.Б. Политика локализации производства как инструмент модернизации Мировая экономика и международные отношения. 2017. Т. 61. № 1. С. 67-77.

11 Моисеева Н.К., Бадорина А.А. Адаптация бизнес-проектов и процессов к условиям локализации производства. Организатор производства. 2015. № 1 (64). С. 56-62.

12 Павлова А.А., Фролов В.Г. Цифровая трансформация и локализация промышленного производства в России как базовые факторы экономического роста. Научные труды Вольного экономического общества России. 2018. Т. 212. № 4. С. 363-385.

13 Минпромторг заключил СПИК с Volkswagen, GM-Avtovaz, PSA, Volvo, Toyota и «Автотором»Российский экспортный центр, 3 июля 2019 г. URL: https://tass.ru/ekonomika/6623742 (дата обращения 08.04.2020)

14 Реализация мер поддержки инвестиционной деятельности. Приоритетные направления. Министерство экономического развития Российской Федерации URL: https:/economy.gov.ru/material/directions/ investicionnaya_deyatelnost/realizaciyamer_podderzhki_investicionnoy_deyatelnosti/_ (дата обращения 09.04.2020)

15 Максим Григорьев. СПИК 2.0: как выглядит новый формат соглашения между инвестором и государством СФЕРА. Информационно-юридический портал https://facademy.ru/sphere/post/spik-20-kak-vyglyadit-novyiformat-soglasheniya-mezhdu-investorom-i-gosudarstvom (дата обращения 08.04.2020) 